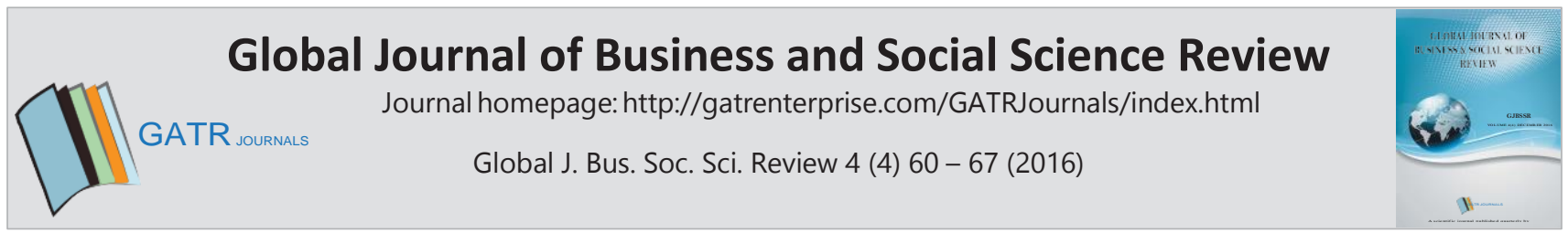

\title{
The Influence of Religion on Grocery Shoppers' Behavioural Intentions in Mauritius Supermarkets
}

\author{
Nazneen Carrim Jackaria* \\ Open University of Mauritius, Reduit, Mauritius
}

\begin{abstract}
Objective - Based on Sheth's (1983) integrative theory of patronage preference as the central theoretical framework, this paper examines religious influences on grocery shoppers' behavioural intentions in Mauritius.

Methodology/Technique - Using stratified random sampling method a 5 point-Likert scale questionnaire was administered. Data from the random sample of 409 grocery shoppers was obtained by a computer aided telephone interview. The sample consisted of 202 Hindus, 71 Muslims and 136 Catholics represent the religious proportion of the Mauritian population.

Findings - Results indicate that religious commitment significantly influences store loyalty, and complaint intentions, but have no significant impact on price sensitivity. Religious affiliation was found to have an impact on complaint intentions only. Understanding how to attract more loyal customers should be an underlying strategy for store managers rather than focusing on short-term profits.

Novelty - Future research should consider how religious commitment mediates self-congruity, trust, commitment and satisfaction and their influence on behavioural intentions. This research is limited as it only considers the behavioural intentions of grocery shoppers in Mauritius. These findings address the gap in the religion domain and shed light on the value of religiosity wherein the market is highly religious as a potential marketing segmentation tool when formulating marketing tactics and implementing marketing strategies
\end{abstract}

Type of Paper: Empirical

Keywords: Complaint, Price, Store Loyalty, Religious Affiliation, Religious Commitment.

JEL Classification: D19, Z12.

\section{Introduction}

Religiosity represents an inherent human value which is fairly stable over a long period of time, many elements of religiosity are observable and therefore of practical value to marketers (McDaniel \& Burnett, 1990). Moreover, religiosity has received theoretical support and widespread media attention focused on the influence of religious beliefs on consumer choices, but empirical research in this area remains scant (Swimberghe, Flurry, \& Parker, 2009). It has been observed globally an upswing towards religious conservatism. This trend raises a number of questions for marketing strategists and retail store managers. For example, will consumers boycott a store if their religious beliefs, values, and ethical standards are in contradiction with the store's policies and actions? Will consumers express their dissatisfaction through posts on social media? Will consumers spread negative word of

\footnotetext{
Paper Info: Revised: September 9, 2016

Accepted: October 23, 2016

* Corresponding author:

E-mail: njackaria@gmail.com

Affiliation: Open University of Mauritius, Reduit, Mauritius
} 
mouth to colleagues, friends, and relatives? Will consumers search for additional information or seek redress from the seller? Will consumers inform the authorities, supermarket managers, Consumer Protection Office, or religious leaders? Will consumers seek legal action?

Thus the main inquiry of this study is "Do consumers' religious beliefs resonate in their behavioral intentions?" More specifically the objective of this research is twofold. This study proffers a model that first examines the relationships between religious commitment and three outcome variables: store complaint intentions, store loyalty and price sensitivity. Second, this research investigates the relationship between religious affiliation and the three behavioural intentions outcomes mentioned above.

\section{Theoretical Framework}

Sheth's (1983) integrative theory of retail store patronage preference and behaviour provides a sound theoretical framework for examining the religious variable within a shopping context. According to Sheth (1983), religious values may impact on shopping behaviour in two ways. First, an indirect path originating from religious influences on personal values; and secondly, a direct path originating from religious influences on the evoked set of retail outlet alternatives. The religiosity construct is therefore expected to significantly influence consumer behavioural intentions when shopping for groceries. It is this relationship between religiosity and behavioral intentions outcome that is explored in the present study.

\subsection{Religious affiliation}

Religious affiliation has been measured according to denominational membership or faith identification of the individual (e.g. Catholic, Protestant, Jews, Hindus and Muslims). One is born into a religious tradition and through the action of its institutional influences (i.e. Sunday school, church, mosque or temple attendance) forms a religious identity or affiliation. Although, some earlier studies have suggested that consumer behaviour is induced by religious affiliation, however, some shortcomings are noted. The strength of religious affiliation was assumed not to differ across religious groups. Thus, it was difficult to distinguish the characteristics of religious affiliation from those of actual religiousness. Moreover, in some research religious affiliation did not have a significant influence on several aspects of buyer behaviour (Heiman, McWilliams \& Zilberman, 2004; McDaniel \& Burnett, 1990). Furthermore, some people may have a preference for one religion, but an affiliation with another (Roof, 1980). As a result of the mixed results with respect to religious affiliation, religious commitment has been found to be a more significant predictor of consumer behaviour in a variety of contexts.

\subsection{Religious commitment}

Religious commitment (the extent to which individuals adhere to a particular religious group) is one of the most important cultural forces and a key influence on buyer behaviour (Delener, 1990). This is because the purchasing decision can be categorised according to how much consumers are committed to a particular faith. Swimberghe, Sharma, \& Flurry (2009) demonstrated that consumer religious commitment significantly influences store loyalty and complaint intentions. Furthermore, taking into consideration the religious commitment of consumers may be beneficial for firms. In addition to the potential value of consumer religiosity as market segmentation variable in exploiting new markets, offending or ignoring religious beliefs of existing consumers may have a detrimental effect on store loyalty and consumer complaint intentions, especially in those markets where the majority of consumers are highly committed to their religion. Swimberghe et al., (2011) found that a consumer's ethical judgment of a firm's potentially religious objectionable decision arose mainly from how one internalizes religious values rather than the participatory or organisational component of the religious experience. In addition, those that increasingly held conservative beliefs, negatively judged businesses that made potentially religious objectionable decisions, compared to their lesser conservative counterparts. 


\section{Hypotheses}

\subsection{Consumer religiosity and complaint intentions}

Highly religious individuals will appraise violations of religious standards as very stressful events and perceive them as threatening to the "self." In accordance with the cognitive-emotive process model of consumer complaint behaviour, stressful events, such as the discord between consumers' religious beliefs and corporate policies, will elicit negative emotive reactions and further result in increased consumer complaint intentions (Stephens \& Gwinner, 1998). In addition, previous studies have concluded that a lack of overlap between the organisation and the self, as well as the resulting emotional reactions expressing that dissatisfaction, may not only lead to switching and negative word-of-mouth but also to increased third-party complaining (Bougie et al., 2003; Brown et al., 2005). Thus, when firms are perceived to violate consumers' religious beliefs, the following hypotheses are proposed:

$\mathrm{H}_{1}$ : There is a significant difference between devout and casually religious consumers in their complaint intentions.

$\mathrm{H}_{2}$ : There is a significant difference between Hindus, Muslims, and Christians in their complaint intentions.

\subsection{Consumer religiosity and store loyalty}

A highly religious individual's self-concept is explicitly linked to his or her religious value system and will play an important role in the evaluation of fit between the consumer, and the image the store portrays. Consequently, businesses supporting causes or enacting policies which are contrary to a consumer's religious belief not only display undesirable non-functional evaluative criteria, but also create a larger distance between the individual's self-concept and the symbolic store image, that leads to a biased interpretation of functional store evaluative criteria. A combination of both, undesirable non-functional evaluation criteria and a biased interpretation of functional evaluative criteria, ultimately results in a decrease in store loyalty (Mason \& Mayer, 1973; Sirgy \& Samli, 1985). Thus, when firms are perceived to violate consumers' religious beliefs the following hypotheses are proposed:

$\mathrm{H}_{3}$ : There is a significant difference between devout and casually religious consumers in their store loyalty intentions.

$\mathrm{H}_{4}$ : There is a significant difference between Hindus, Muslims, and Christians in their store loyalty intentions.

\subsection{Consumer religiosity and price sensitivity}

Essoo and Dibb (2004) findings suggest that casually religious consumers are more practical in their shopping behaviour than devout consumers, attaching more importance to price deals and credit availability. Shah Alam, Mohd and Hisham (2011) indicated that those high in religiosity tend to be less impulsive when making purchase decisions. This is consistent with literature which suggests that highly religious individuals tend to behave in a relatively more mature, disciplined and responsible manner. The degree of religiosity of consumers might manifest themselves on the importance attached to financial purchase factors, such as the use of cash or credit. Cash purchases usually require greater self-restraint and discipline than credit purchases. Therefore, highly religious individuals are expected to attach less importance to credit availability than their less religious counterparts.

$\mathrm{H}_{5}$ : There is a significant difference between devout and casually religious consumers in their price sensitivity.

$\mathrm{H}_{6}$ : There is a significant difference between Hindus, Muslims, and Christians in their price sensitivity. 


\section{Methodology}

\subsection{Measures}

A 12-item religious commitment index was built by drawing and adapting ten of the items from the Religious Commitment Inventory (RCI-10) scale developed by Worthington et al., (2003). The remaining two items were developed by the researcher. Religious affiliation was measured by asking respondents the following question: "With which religion do you identify yourself?" Only Hindu, Muslims, and Christians, respondents were considered for this survey. Store loyalty was measured using a five- item scale. Three items were drawn from the scale developed by Sirohi et al. (1998) used for measuring the intent to remain loyal to the store. Price sensitivity comprises of a three-item scale and was measured with scales derived from Stock (2005) and Low et al., (2013) but which have been adapted to match the retail grocery setting. A nine-item scale was developed for measuring the likelihood that a consumer would aim complaints at those marketers (e.g. salespersons, managers or owners) perceived as being involved in the offensive practices/policies (Swimberghe et al., 2009).

\subsection{Data collection and sample characteristics}

The research data was collected by means of computer aided telephone interviews. Using the stratified random sampling procedure, four hundred and nine respondents were randomly sampled for this study. $49.1 \%$ of the respondents $(n=201)$ were males and $50.9 \%$ females $(n=208)$ respectively in line with the proportion of gender of the population. The sample was made up of $49.4 \%$ Hindus $(n=202), 17.4 \%$ Muslims $(n=71)$ and $33.2 \%$ per cent Christians $(\mathrm{n}=136) .14 .4 \%$ of the respondents $(\mathrm{n}=59)$ were between $18-24$ years old constituting the youngest group. $40.1 \%$ of the respondents $(n=164)$ were between $25-44$ years old, $35.2 \%$ of the respondents $(n=144)$ were between $45-64$ years and $10.3 \%$ of the respondents $(n=42)$ were $65+$. The sample was split according to age group in proportion to the population.

\section{Results}

\subsection{Factor formation}

Principal components analysis was performed to reduce the dimensionality of the twenty-three behavioural intentions (BI) statements and summarise the information in a smaller set of variables. Six items were excluded because of the factor loading $<0.4$. Factor analysis was therefore conducted on the remaining seventeen BI statements. The KMO test of sample adequacy was 0.849. Bartlett's Test of Sphericity value of 2201.799 (p < $.000)$ indicate that the data matrix has sufficient correlation to proceed with factor analysis. Factor extraction was set fixed for three factors only. The three factors had a cumulative total variance explained of 50.023. The Rotated Component Matrix show that 17 variables loaded most heavily on three factors. Nine variables loaded on the first factor (Complaint Intentions), five variables loaded on the second factor (Store Loyalty) and three variables loaded on the third factor (Price Sensitivity).

Table1. Summary of Factor Analysis

\begin{tabular}{|l|l|l|l|l|l|}
\hline \multicolumn{1}{|c|}{ Label } & Eigenvalue & $\begin{array}{c}\text { No. of } \\
\text { Factor }\end{array}$ & $\begin{array}{c}\text { Factor } \\
\text { Loading }\end{array}$ & $\begin{array}{c}\text { Rotated } \\
\text { Cumulative\% } \\
\text { of Total } \\
\text { Variance } \\
\text { Explained }\end{array}$ & $\begin{array}{c}\text { Cronbach } \\
\alpha\end{array}$ \\
\hline Complaint Intentions & 4.852 & 9 & $.634-.817$ & 28.542 & .890 \\
\hline Store Loyalty & 1.949 & 5 & $.490-.724$ & 11.466 & .604 \\
\hline Price Sensitivity & 1.703 & 3 & $.660-.723$ & 10.015 & .533 \\
\hline
\end{tabular}




\subsection{Testing of hypotheses}

A t-test was used to test the statistical differences between the means for each of the behavioural intention factors between devout and casually religious consumers (Table 2). Factors of which both samples had a variation, were complaint intentions $(\mathrm{t}=-4.4, \mathrm{p}<.001)$ and store loyalty $(\mathrm{t}=-2.07, \mathrm{p}<.05)$. Thus, $\mathrm{H} 1$ and $\mathrm{H} 3$ were substantiated. The effect size was larger for complaint intentions (Cohen's d=.4362) as compared to store loyalty (Cohen's $\mathrm{d}=.2052$ ). However, there was no significant difference in price sensitivity. Thus, H5 was rejected.

Table2. Mean, SD, and t-tests

\begin{tabular}{|l|l|l|ll|l|l|}
\hline & \multicolumn{2}{|c|}{ Casually Religious } & \multicolumn{2}{c|}{ Devout } & \multirow{2}{*}{ t } & \multirow{2}{*}{ Sig. } \\
\hline Mean & S.D. & Mean & S.D. & & \\
\hline Complaint Intentions & 2.604 & .7794 & 2.956 & .8381 & -4.400 & .000 \\
\hline Store Loyalty & 3.728 & .4893 & 3.831 & .5220 & -2.070 & .039 \\
\hline Price Sensitivity & 3.641 & .7097 & 3.717 & .6684 & -1.125 & .261 \\
\hline
\end{tabular}

Table 3 shows the results of one-way ANOVA investigating differences in behavioural intention factors and religious affiliation. The test statistics for complaint intention $(\mathrm{F}=13.78)$ indicates a significant difference at $\mathrm{p}$ $<0.01$ level. Thus, H2 was supported. Multiple comparisons show that there were significant differences in complaint intention between Hindus and Muslims $(\mathrm{p}<0.001)$ and Muslims and Catholics $(\mathrm{p}<0.001)$. No support was found for $\mathrm{H} 4$ and $\mathrm{H} 6$.

Table3. One-Way ANOVA

\begin{tabular}{|c|c|c|c|c|c|c|c|c|}
\hline & \multicolumn{3}{|c|}{ Mean } & \multicolumn{3}{|c|}{ Standard Deviation } & \multirow{2}{*}{$\mathrm{F}$} & \multirow{2}{*}{ Sig } \\
\hline & $\mathrm{H}$ & $\mathrm{M}$ & $\mathrm{C}$ & $\mathrm{H}$ & M & $\mathrm{C}$ & & \\
\hline Complaint & 2.778 & 3.186 & 2.569 & .7942 & .8472 & .7908 & 13.780 & .000 \\
\hline Store Loyalty & 3.816 & 3.817 & 3.706 & .4676 & .5406 & .5427 & 2.150 & .118 \\
\hline Price & 3.635 & 3.747 & 3.708 & .6538 & .6654 & .7519 & .868 & .421 \\
\hline
\end{tabular}

\section{Conclusion and Discussion}

The findings showed that the degree of religious commitment influences both complaint intentions and store loyalty, but no significant relationship was found between religious commitment and price sensitivity of grocery shoppers. This positive link sheds light that in a highly multi-religious consumer market like Mauritius the degree of religiosity of grocery shoppers influences their complaint and loyalty intentions as religious persons have value systems that differ from less religious and non-religious persons. These findings receive support from extant literature. Swimberghe et al. (2009) found a positive relationship between religious commitment and complaining behaviour when students were confronted with a seller who supported a potentially religious controversial business decision. Hunt and Vitell $(1986,1993)$ mentioned that customer loyalty will suffer when sellers make potentially religious objectionable business decisions which customers find morally unacceptable. Consumers do evaluate sellers' actions and form ethical judgments. These judgments dictate consumers' store loyalty intentions (Swimberghe et al., 2011).

However, no relationship was found between price sensitivity and religious commitment of grocery shoppers. This observation can be explained by the fact that grocery products are purchased mostly on a cash basis, characterized as low involvement product category and non-durable products (i.e. fast moving consumer goods), purchased on a frequent basis therefore not much information search is involved. Consequently, personal determinants (personal, social and epistemic values) of customers in relation to price sensitivity are not manifested when shopping for groceries due to the inherent characteristics of grocery items. Malik and Malik (2013) established that consumer behaviour varies with the level of involvement and the degree of religiosity and to better understand the intricacies of consumers' behaviour, their purchasing habits should be studied in the context of varying levels of religiosity and product involvement. 
Second, this study investigated whether a linkage exists between religious affiliation and behavioural intentions of grocery shoppers. A significant relationship was found only for complaint intentions. Moreover, it was found a marked difference between religious groups Hindus and Muslims and Muslims and Catholics. However, no difference was found between Hindus and Catholics. This finding is in line with earlier studies into the influence of religious affiliation on consumer behaviour (e.g. McDaniel \& Burnett, 1990; Bailey \& Sood 1993; Delener, 1994; Essoo \& Dibb 2004; Fam, Waller \& Erdogan, 2004; Lindridge, 2005). With regard to the lack of support for $\mathrm{H} 4$ and $\mathrm{H} 6$ dealing with religious affiliation, it could be due to the fact that religious affiliation classifications tend to be too operationally vague to produce consistent results (McDaniel \& Burnett, 1990). This finding contributes to existing literature by also recognising the value of religious affiliation as a potential variable for consumer segmentation and predictor in the event of a 'dissatisfying marketplace experience.' Altogether religious affiliation remains a weak predictor of behavioural intentions.

The overall findings of this research further reassert that religious commitment is a more reliable and stable construct compared to religious affiliation in consumer research and may be used as a potentially powerful predictor and determinant of consumer behaviour. This study contributes to current literature as the first piece of empirical evidence to explore the relationship between religion and consumer behavioural intentions in a nonwesternised cultural setting-Mauritius.

\section{Managerial Implications}

The practical value of this study for retail store marketers highlights the importance of recognising the degree of consumers' religiosity when developing new products and services and formulating marketing tactics and implementing marketing strategies. This study further evidenced that business practices which are in discord with consumers' religious beliefs, values, identity, moral training or ethics are likely to exhibit behaviours signalling they are poised to leave the company or spend less with the company. All the nine factors of complaint intentions exhibit high factor loadings an indication to supermarket retailers that implementing policies or engaging in unrighteous activities against consumers' religious values, beliefs, ethical standards and self-concept may lead to consumers sanctioning the supermarket and taking actions like spreading negative word of mouth, negative public relations and boycotting the store altogether.

In highly religious markets, marketing strategists and store retailers should recognise the sensitive nature of religiously committed consumers so as not to offend them in their advertising campaigns, publicly taking sides or forming alliances with organisations which do not uphold similar religious values and ethical practices as the latter. Failing to do so may have a detrimental effect on store loyalty and increasing complaint intentions of existing customers and in the long term resulting in lower sales and profit margins (Swimberghe et al., 2009) and ultimately damaging the goodwill of the store due to negative store image and further boycotts.

In the highly competitive grocery industry with low differentiated products of comparable quality, ascertaining customer loyalty with a particular retail store is a difficult endeavour. Therefore, at a strategic level, understanding how to attract more loyal customers should be an underlying strategy for store managers rather than focusing on short-term profits (e.g. price discounts, coupons, gifts, loyalty cards) that do not enhance store loyalty (Pettijohn, 2009) but rather lead to a price war. For instance, celebration of religious festivities (Christmas, Diwali or Ramadan) should be part of the company's policies and practices and this should be visible and vocal for consumers to notice, identify with it and act on it. This would help establish, develop and maintain quality relationship with customers. Moreover, stores may also charge a higher price because these customers value maintaining a relationship.

\section{Limitations and Future Research}

The findings presented in this paper are limited to the purchase of grocery items within one country which are confined to the purchase of routine, low risks, and low involvement products (i.e. fast moving consumer goods). It is, therefore, difficult to generalise about the relevance of the results to items that are higher involvement. 
Future research should consider the inclusion of both low and high involvement products so that our general understanding of the influence of religion on behavioural intentions would be improved. This study is limited to grocery stores, however, it would be interesting to investigate whether religious commitment helps in explaining behavioural intentions at different types of stores- for example, department stores vs. grocery stores. Future studies might build on the present findings to explore another facet of religiosity that is religio-centrism and mediating variables such as self-congruity, trust, commitment and satisfaction and their influence on behavioural intentions. A more elaborate religious grouping should also give more meaningful results.

\section{References}

Bailey, JM., \& Sood, J. (1993). The effects of religious affiliation on consumer behaviour: a preliminary investigation . Journal of Managerial Issues, 3(3), 328-352.

Bougie, R., Pieters R., \& Zeelenberg, Y. (2003). "Angry customers don't come back, they get back: the experience and behavioral implications of anger and dissatisfaction in service". Journal of the Academy of Marketing Science, (31), 377-393.

Brown, T.J., Barry, T.E., Dacin, P.A., \& Gunst, R.F. (2005). "Spreading the word: investigating antecedents of consumers' positive word-of-mouth intentions and behaviours in a retailing context". Journal of the Academy of Marketing Science, (33), 123-138.

Delener, N. (1994). Religious contrasts in consumer decision behaviour patterns: Their dimensions and marketing implications. European Jounal of Marketing, 28(5), 36-53.

Essoo, N., \& Dibb, S. (2004). Religious influences on shopping behaviour: An exploratory study. Journal of Marketing Management, 20(7-8), 683-712.

Fam, K. S., Waller, D. S., \& Erdogan, B. Z. (2004). The influence of religion on attitude towards the advertising of controversial products. European Journal of Marketing, 38(5/6), 537-555.

Heiman, A., Just, D., McWilliams, B., \& Zilberman, D. (2004). Religion, religiosity, lifestyles and food consumption. Agriculture Resource Economics, 8(2), 9-11.

Hunt, S. D., \& S. J. Vitell. (1986). 'A General Theory of Marketing Ethics', Journal of Macromarketing (8), 5-16.

Hunt, S. D., \& S. J. Vitell. (1993). 'The General Theory of Marketing Ethics: A Retrospective and Revision', in N. C. Smith and J. A. Quelch (eds.), Ethics in Marketing (Irwin, Homewood, IL), 775-784.

Lindridge, A. (2005). Religiosity and the construction of a cultural- consumption identitiy. Journal of Consumer Marketing, $22(2 / 3), 101-112$.

Low, W. S., Lee, J. D., \& Cheng, S. M. (2013). The link between customer satisfaction and price sensitivity: An investigation of retailing industry in Taiwan. Journal of Retailing and Consumer Services, 20(1), 1-10.

Malik, S. Y., \& Malik, M. S. (2013). Evaluating the influences of religiosity and product invovlement level on the consumers. Journal of Islamic Marketing, 4(2), 163-186.

Mason, J.B., Mayer, M.L. (1973). "Insight into the image determinants of fashion specialty outlets". Journal of Business Research, (1), 73-80.

McDaniel, S. W., \& Burnett, J. J. (1990). Consumer religiosity and retail store evaluative criteria. Journal of the Academy of Marketing Science, 18(2), 101-112.

Parker, R., Pettijohn, C. E., \& Rozell, E.J. (2009). Has Grocery Store Loyalty Changed? An Analysis of Determining Characteristics and Strategy. Journal of Foodservice Business Research, 12, 72-83.

Roof, Wade Clark. (1980). "The Ambiguities of 'Religious Preference' in Survey Research.- A Methodological Note." Public Opinion Quarterly, 44 (Fall), 403-407.

Shah Alam, S., Mohd, R., \& Hisham, B. (2011). Is religiosity an important determinant of Muslim consumer behaviour in Malaysia?. Journal of Islamic Marketing, 2(1), 83-96.

Sheth, Jagdish N. (1983). "An integrative theory of patronage preference and behavior", in Darden, W.R. and Lusch, R.F. (Eds), Patronage Behavior and Retail Management, North Holland, New York, NY, 9-28.

Sirgy, J.M., \& Samli, A.C. (1985). "A path analytic model of store loyalty involving self-concept, store image, geographic loyalty, and socioeconomic status". Academy of Marketing Science, (13), 265-291.

Sirohi, N., McLaughlin, E. W., \& Wittink, D.R. (1998). A model of consumer pereptions and store loyalty intentions for a supermarket retailer. Journal of Retailing, 74(2), 223-245.

Stephens, N.,Gwinner, K.P. (1998). "Why don’t some people complain? A cognitive-emotive process model of consumer complaint behavior". Journal of the Academy of Marketing Science, (26), 172-189.

Stock, R.M. (2005). Can customer satisfaction decrease price sensitivity in business-to-business markets? Journal of Business- to-Business Marketing, 12(3), 59-87. 
Swimberghe, K. R., Sharma, D., \& Flurry, L. W. (2011). Does a consumer's religion really matter in the buyer-seller dyad? An emprirical study examining the relationship between consumer religious commitment, Christian conservatism and the ethical judgment of a seller's controversial business decision. Journal of Business Ethics, 102(4), 581-598.

Swimberghe, K., Flurry, L. A., \& Parker, J. M. (2011). Consumer religiosity: Consequences for consumer activism in the United States. Journal of Business Ethics, 103(3), 453-467.

Swimberghe, K., Sharma, D., \& Flurry, L. (2009). An explanatory investigation of the consumer religious commitment and its influence on store loyalty and consumer complaint intentions. Journal of Consumer Marketing, 26(5), 340-347.

Worthington, E.L., Wade, N.G., Hight, T.L., Ripley, J.S., McCullough, M.E., Berry, J.W., Schmitt, M.M., Berry, J.T., Bursley, K.H. and O'Connor, L. (2003), "The religious commitment inventory-10: development, refinement, and validation of a brief scale for research and counseling". Journal of Counseling Psychology, (50), 84-96. 